\title{
Artistas e intelectuais no Brasil pós-1960
}

Marcelo Ridenti

I sso é queé, na verdade, a Revolução Brasileira. [...] ela ganha carne, densidade, penetra fundo na alma dos homens. 0 rio que vinha avolumando suas águas e aprofundando seu leito, até março de 1964, desapareceu de nossas vistas. M as um rio não acaba assim. Ele continua seu curso, subterraneamente, equem tem bom ouvido pode escutar-Ihe o rumor debaixo da terra. Ferreira Gullar (1967, p. 253).

Nota introdutória

Este artigo retoma a reflexão do livro Em busca do povo brasileiro (cf. Ridenti, 2000). Além da análise de novos casos, recorre-se à noção de "estrutura de sentimento", formulada por Raymond W illiams, esecundariamente às noções de "campo" em Bourdieu, de declínio da intelectualidade em Jacoby e de outras não usadas naquele livro. Busca-se, assim, avançar na compreensão do tema da relação entre cultura e política nos anos de 1960 e 1970, em particular na análise sociológica da vasta e diferenciada produção artística brasileira.

Estrutura de sentimento da brasilidade revolucionária nos anos de 1960

Partir das reflexões de R aymond W illiams sobre as "estruturas de sentimento" constitui uma possibilidade de aproximação teórica para tratar, especialmente no que se refere às artes, do tema do surgimento de um imagi- 
1. H áoutro aspecto fascinante, que não será explorado aqui, queimplicaria fazer o caminho inverso: em vez de partir dos anos de 1960 paraaatualidade, tomá losem referência ao seu passado. Isso envolveria refletir mais demoradamente sobre 0 fato de que a utopia da brasilidaderevolucionáriatem raízes também na ideologia das representações da mistura do branco, do negro e do índio na constituição dabrasilida de, tão caras, por exemplo, ao pensamento conservador de Gilberto Freyre. $\mathrm{N}$ a década de 1960, formulavam-se novas versões para essas representações, não mais no sentido de justificar a ordem social existente, mas dequestioná-la: - Brasil não seria ainda - país da integração entre as raças, da harmoniaedafelicidadedo povo, impedido pelo poder do latifúndio, do imperialismo e, no limite, do capital. M as poderia vir a sếlo como conseqüência da "revolução brasileira", pelo que se chegava a pensar numa "civilização brasileira", retomando à nário crítico nos meios artísticos e intelectuais brasileiros na década de 1960 e depois sua transformação e (re)inserção institucional a partir dos anos de 1970¹. Talvez se possa falar na criação de uma "estrutura de sentimento" compartilhada por amplos setores de artistas e intelectuais brasileiros a partir do final dos anos de 1950, e de como ela se transformou ao longo do tempo. W illiams reconhece que "o termo é difícil, mas 'sentimento' é escolhido para ressaltar uma distinção dos conceitos mais formais de 'visão de mundo' ou 'ideologia'", os quais se referem a crenças mantidas de maneira formal esistemática, ao passo que uma estrutura de sentimento daria conta de "significados e val ores tal como são sentidos e vividos ativamente". A estrutura de sentimento não se contrapõe a pensamento, mas procura dar conta "do pensamento tal como sentido e do sentimento tal como pensado: a consciência prática de um tipo presente, numa continuidade viva einter-relacionada", sendo por isso uma hipótese cultural derelevância especial para a arte e a literatura (W illiams, 1979, pp. 134-135).

Segundo M aria Elisa C evasco, o termo foi cunhado por W illiams para "descrever como nossas práticas sociais e hábitos mentais se coordenam com as formas de produção e de organização socioeconômica que as estruturam em termos do sentido que consignamos à experiência do vivido" (C evasco, 2001, p. 97). Para essa autora

[...] trata-se de descrever a presença de elementos comuns a várias obras de arte do mesmo período histórico que não podem ser descritos apenas formalmente, ou parafraseados como afirmativas sobreo mundo: a estrutura de sentimento éa articulação de uma resposta a mudanças determinadas na organização social (Idem, p. 153).

0 caráter de experiência viva que o conceito de estrutura de sentimento tenta apreender faz com que essa estrutura nem sempre seja perceptível para os artistas no momento em que a constituem. Torna-se clara, no entanto, com a passagem do tempo que a consolida - e também ultrapassa, transforma e supera. $\mathrm{N}$ as palavras de W illiams,

[...] quando essa estrutura de sentimento tiver sido absorvida, são as conexões, as correspondências, e até mesmo as semelhanças de época, que mais saltam à vista. 0 que era então uma estrutura vivida, é agora uma estrutura registrada, que pode ser examinada, identificada e até generalizada (1987, pp. 18-19). 
N esse sentido, hoje se pode identificar com clareza uma estrutura de sentimento que perpassou boa parte das obras de arte a partir do fim da década de 1950. Ela poderia ser chamada de diferentes modos - necessariamente limitadores, pois uma denominação sintética dificilmente seria capaz de dar conta da complexidade e da diversidade do fenômeno. Pode se propor, sem excluir outras possibilidades, que seja chamada de estrutura de sentimento da brasilidade (romântico-) revolucionária.

Essa expressão leva a um outro conceito, útil para compreender a estrutura de sentimento da brasilidade revolucionária: o de "romantismo", tal como formulado por Löwy e Sayre (1995). Para esses autores, o romantismo não seria apenas uma corrente artística nascida na Europa na época da revolução francesa e que não passou do século XIX. M uito mais que isso, seria uma visão de mundo ampla, "uma resposta a essa transformação mais lenta e profunda - de ordem econômica e social - que é o advento do capitalismo", e que se desenvolve em todas as partes do mundo até nossos dias (Löwy e Sayre, pp. 33-36).

A crítica a partir de uma visão de mundo romântica incidiria sobre a modernidade como totalidade complexa, que envolveria as relações de produção (centradas no valor de troca eno dinheiro, sob o capitalismo), os meios de produção e o Estado. Seria uma "autocrítica da modernidade", uma reação formulada de dentro dela própria, não do exterior, "caracterizada pela convicção dolorosa e melancólica de que o presente carece de certos valores humanos essenciais que foram alienados" no passado e que seria preciso recuperar (Idem, pp. 38-40).

0 romantismo seria então um fenômeno vasto, com diversas expressões artísticas e também políticas, o que permitiria constituir uma tipologia, "indo grosso modo da direita para a esquerda": romantismo restitucionista, conservador, fascista, resignado, reformador e revolucionário ou utópico. Este último visaria a

[...] instaurar um futuro novo, no qual a humanidade encontraria uma parte das qua lidades evalores quetinha perdido com a modernidade: comunidade, gratuidade, doa ção, harmonia com a natureza, trabal ho como arte, encantamento da vida. N o entanto, tal situação implica o questionamento radical do sistema econômico baseado no valor de troca, lucro e mecanismo cego do mercado: o capitalismo (Idem, p. 325).

N esse caso, "a lembrança do passado serve como arma para lutar pelo futuro" (Idem, p. 44). esquerda a utopia do período Vargas. 
A hipótese proposta em meu livro Em busca do povo brasileiro (cf. Ridenti, 2000) é a de que o florescimento cultural e político dos anos de 1960 e início dos de 1970 na sociedade brasileira pode ser caracterizado como romântico-revolucionário. Valorizava-se acima de tudo a vontade de transformação, a ação para mudar a $\mathrm{H}$ istória e para construir o homem novo, como propunha $C$ he Guevara, recuperando o jovem $M$ arx. M as o modelo para esse homem novo estava, paradoxalmente, no passado, na idealização de um autêntico homem do povo, com raízes rurais, do interior, do "coração do Brasil", supostamente não contaminado pela modernidade urbana capitalista.

Vislumbrava-se uma alternativa de modernização que não implicasse a submissão ao fetichismo da mercadoria e do dinheiro, gerador da desumanização. A questão da identidade nacional e política do povo brasileiro estava recolocada, buscava-se ao mesmo tempo recuperar suas raízes e romper com o subdesenvolvimento, o que não deixa de ser um desdobramento à esquerda da chamada era Vargas, propositora do desenvolvimento nacional com base na intervenção do Estado.

É polêmico caracterizar como romântico-revolucionárias a cultura e a política de parte significativa das esquerdas nos anos de 1960, já que romantismo costuma ser associado à reação, não à revolução (cf. Romano, 1981). M as o conceito não deixa de ser interessante justamente pela sua ambigüidade - que possivelmente tem paralelo com a do objeto em estudo. No contexto social, econômico, político e cultural brasileiro a partir

2.0 utro aspecto interessante do uso dessa acepção do romantismo revolucionário éque ele permite compreender as afinidades ao longo do tempo com outras estruturas desentimento românticas, por ve zesconservadoras. Abre se uma pista para compreender a trajetória aparentemente contraditória de artistas como Glauber Rocha, que foram integralistas na mocidade. do final dos anos de 1950, recuperar o passado na contramão da modernidade era indissociável das utopias de construção do futuro, que vislumbravam o horizonte do socialismo. Por isso devem ser relativizadas algumas análises, como a de Sérgio Paulo Rouanet, para quem o povo das esquerdas "dos anos 60 tinha muitas vezes uma semelhança inconfortável com 0 volk do romantismo alemão [...]: a nação como individualidade única, representada pelo povo, como singularidade irredutível" (1988, p. D.3). O ra, a semelhança não geraria desconforto, pois não se tratava da mesma coisa, embora ambos fossem parecidos em alguns aspectos, ao resgatar as idéias de povo e nação para posicionar-se na contramão do capitalismo. N aquele contexto brasileiro, a valorização do povo não significava criar utopias anticapitalistas passadistas, mas progressistas; implicava o paradoxo de buscar no passado (as raízes populares nacionais) as bases para construir o futuro de uma revolução nacional modernizante que, ao final do processo, poderia romper as fronteiras do capitalismo². 
Aqueles que compartilhavam da estrutura de sentimento da brasilidade revolucionária tinham relação ambígua com a ordem estabelecida no pré 1964, principalmentecom o governo G oulart, que contava com o apoio de vários artistas e intelectuais. $D$ ifundia-sena época o dual ismo que apontava a sobreposição de um Brasil moderno a outro atrasado. A "razão dualista" para usar o termo de Francisco de O liveira (1972) - era disseminada pelos teóricos do Instituto Superior de Estudos Brasileiros (ISEB), pela Comissão Econômica para a América Latina (C epal), organismo das N ações U nidas, e pelo Partido Comunista Brasileiro (PCB), cuja teoria das duas etapas da revolução brasileira era incorporada difusa e diversamente pelos artistas que compartilhavam daquela estrutura de sentimento. $\mathrm{N}$ a versão do PCB do dualismo, haveria resquícios feudais ou semifeudais no campo, a serem removidos por uma revolução burguesa, nacional e democrática que uniria todas as forças interessadas no progresso da nação e na ruptura com o subdesenvolvimento (a burguesia, o proletariado, os setores das camadas mé dias e também os camponeses), contra as forças interessadas em manter 0 subdesenvolvimento brasileiro, a saber, o imperialismo e seus aliados internos, os latifundiários e os setores das camadas médias próximos dos interesses multinacionais. A revolução socialista viria numa segunda etapa - bem próxima ou ainda muito distante, dependendo da corrente partidária (cf. Prado J r., 1966).

$N$ esse sentido, a estrutura de sentimento da brasilidade revolucionária não nasceu do combate à ditadura, mas vinha de antes, forjada no período democrático entre 1946 e 1964, especialmente no governo G oulart, quando diversos artistas e intelectuais acreditavam estar na crista da onda da revolução brasileira em curso. A quebra de expectativa com o golpe de 1964 - ainda mais sem resistência - foi avassaladora também nos meios artísticos e intelectualizados, como atestam o artigo clássico de Roberto Schwarz, publicado pela primeira vez em 1970 na França, e o depoimento de Chico Buarque em 1999:

$\mathrm{N}$ os anos 50 havia mesmo um projeto coletivo, ainda que difuso, de um Brasil possível, antes mesmo de haver a radicalização de esquerda dos anos 60. 0 Juscelino, que de esquerda não tinha nada, chamou o 0 scar N iemeyer, que por acaso era comunista, e continua sendo, para construir Brasília. Isso é uma coisa fenomenal. [...] Ela foi construída sustentada numa idéia daquele Brasil que era visível para todos nós, que estávamos fazendo música, teatro etc. Aquele Brasil foi cortado evidentemente em 64. Além da tortura, de todos os horrores de que eu poderia 
3. Essas palavras trazem o eco da referida interpretação de Schwarz, para quem o país estava "irreconhecivelmente inteligente" no pré1964 (cf. Schwarz, 1978).

4. Callado, naépocaem queescreveu o livro, estavaorganicamentevinculado à guerrilha comandada por Leonel Brizola, conforme admiteexpressamente em longa entrevista a mim concedida sobre o tema epublicada quasenaíntegra em "A guerrilha de Antonio Callado" (apud Kushnir, 2002, pp. 23-53).

5.0 s próprios autores quecompartilhavam da estrutura de sentimento da brasilidade revolucionária que amadurecera no pré-1964 começaram a problematizála apóso golpe Tanto que, no tão almejado centro do Brasil que se procurava em Q uarup, o que se encontrou foi um grande formigueiro (cf. Callado, 1967). falar, houve um emburrecimento do país. A perspectiva do país foi dissipada pelo golpe (Buarque, 1999, p. 4.8)³.

São exemplos expressivos da estrutura de sentimento romântica e revolucionária - para amalgamar num único termo as propostas de W illiams, Löwy e Sayre - desenvolvida no Brasil no início dos anos de 1960: a) a trilogia clássica do início do C inema N ovo, todos filmes rodados em 1963 e exibidos já depois do golpe - Vidas secas, de N elson Pereira dos Santos; D euse o D iabo na terra do sol, de G lauber Rocha; e O sfuzis, de Ruy Guerra -; b) a dramaturgia do Teatro de Arena de São Paulo (de autores como Gianfrancesco Guarnieri, Augusto Boal, Francisco de Assis e 0 duvaldo Vianna Filho, o Vianinha), e também de autores como D ias Gomes; c) a canção engajada de C arlos Lyra e Sérgio Ricardo; d) o agitprop dos C entros Populares de Cultura (CPCs) da U nião N acional dos Estudantes, especialmente em teatro, música, cinema e literatura - como os três livros da coleção Violão de rua (Felix, 1962; 1963), com o subtítulo revelador de poemas para a liberdade, cujo poeta mais destacado foi Ferreira Gullar, ou ainda o filme Cinco vezes favela, dirigido por jovens cineastas, entre eles Carlos D iegues, Leon H irzman e Joaquim Pedro de Andrade.

D epois do golpe de 1964, essa estrutura de sentimento da brasilidade (romântico-) revolucionária pode ser encontrada nas canções de Edu Lobo, G eraldo Vandré e outros; nos desdobramentos da dramaturgia do Teatro de Arena - como a peça Arena conta Zumbi e sua celebração da comunidade negra revoltosa; e especialmente no romance $Q$ uarup, de Antonio $C$ allado (1967), que exaltava a comunidade indígena e terminava apontando a via da revolução social ${ }^{4}$, e que foi chamado por Ferreira Gullar de "ensaio de deseducação para brasileiro virar gente". G ullar observa que,

[...] enquanto lia o romance, não podia deixar de pensar nos índios de $G$ onçalves Dias, em Iracema de Alencar, em M acunaíma de M ário de Andrade, em Cobra N orato, mesmo nos Sertões, de Euclides, em Guimarães Rosa. Pensava na abertura da Belém-Brasília, no Brasil, nesta vasta nebulosa de misto e verdade, de artesanato e eletrônica, deselva ecidade, quese elabora, quese indaga, quese vai definindo (Gullar, 1967) .

Essas palavras - e o conjunto da resenha em que se insere - resumem bem a estrutura de sentimento da brasilidade revolucionária. 
As obras citadas buscam no passado uma cultura popular autêntica para construir uma nova nação, ao mesmo tempo moderna e desalienada. D eixam transparecer certa evocação da liberdade no sentido da utopia romântica do povo-nação, regenerador e redentor da humanidade (cf. Saliba, 1991, pp. 53-67). Revelam a emoção e a solidariedade dos autores com 0 sofrimento do próximo, a denúncia das condições de vida subumanas nas grandes cidades e, sobretudo, no campo. Enfoca-se especial mente o drama dos retirantes nordestinos. A questão do latifúndio e da reforma agrária é recorrente, em geral associada à conclamação ao povo brasileiro para realizar sua revolução, em sintonia com as lutas de povos pobres da América Latina e do Terceiro M undo.

O s artistas engajados das classes médias urbanas identificavam-se com os deserdados da terra, ainda no campo ou migrantes nas cidades, como principal personificação do caráter do povo brasileiro, a quem seria preciso ensinar a lutar politicamente. Propunha-se uma arte nacional-popular que colaborasse com a desalienação das consciências. Recusava-se a ordem social instituída por latifundiários, imperialistas e - no limite, em alguns casos - pelo capitalismo. Compartilhava-se certo mal-estar pela suposta perda da humanidade, acompanhado da nostal gia melancólica de uma comunidade mítica já não existente, mas esse sentimento não se dissociava da empolgação com a busca do que estava perdido, por intermédio da revolução brasileira. Podese mesmo dizer que predominava a empolgação com o "novo", com a possibilidade de construir naquele momento o "país do futuro", mesmo remetendo a tradições do passado.

Sem dúvida, essa estrutura de sentimento era portadora de uma idealização do homem do povo, especialmente do campo, pelas classes médias urbanas. M as ela se ancorava numa base real: a insurgência dos movimentos de trabal hadores rurais no período. Era o tempo das Ligas $C$ amponesas, cel ebradas em obras como J oão Boa-M orte (cabra marcado para morrer), de Ferreira Gullar, ou no filme de Eduardo C outinho, inacabado à época, que tomou emprestado o subtítulo do poema de Gullar ${ }^{6}$. Ademais, vivia-se 0 impacto de revoluções camponesas no exterior, especialmente em Cuba e no Vietnã. Também é preciso lembrar que a sociedade brasileira ainda era predominantemente agrária pelo menos até 1960; estava em andamento um dos processos de urbanização mais rápidos da história mundial: de 1950 a 1970, a sociedade brasileira passou de majoritariamente rural para eminentemente urbana, com todos os problemas sociais e culturais de uma transformação tão acelerada.
6.0 s operários também eram tematizados, como na peça pioneira de Guarnieri Eles não usam black-tie, encenada pelo Teatro de Are na em 1958, mas com menor intensidade que ostrabalhadores rurais. $M$ as era a categoria de povo que, acima das classes, tendia a predominar nessa estrutura de sentimento: os pobres, seres humanos miseráveis, desumanizados, de serdados da terra. 
Pode-se ver que a experiência viva da estrutura de sentimento da brasilidade revolucionária tem uma história peculiar ao devir das artes e da cultura no Brasil, ao mesmo tempo em que está sintonizada com o cenário cultural e político internacional. Pólos contraditórios conviviam em diferentes intensi dades e arrumações internas em diversos movimentos e obras de artistas específicos: brasilidade e internacionalização; passado e futuro; raízes culturais e modernidade.

Brasilidade-mundo

É esclarecedora a constatação de C arlos D iegues numa entrevista: "a minha geração foi a última safra de uma série de redescobridores do Brasil. O Brasil começa a se conhecer, sobretudo com o romantismo [...] aquele desejo de uma identidade [...]. M inha geração, do Cinema N ovo, do tropi-

7.Entrevista a Zuleika Bueno.

8. Procurei desenvolver essa idéia, no tocantea Chico Buarque, no texto "Visões do paraíso perdido" (cf. Ridenti, 2000, pp. 225-264). calismo, é a última representação desse esforço secular"7. A tradição cultural de busca da identidade nacional atravessou todo o século XX. N ão éà toa que dois destacados artistas dos anos de 1960 - o cineasta C arlos D iegues e 0 compositor $\mathrm{C}$ hico Buarque - são filhos respectivamente de dois pensadores da brasilidade: $M$ anoel Diegues J r. e Sérgio Buarque de H ollanda. Tampouco é acaso que Chico Buarque tenha feito a letra da canção Bye, bye, Brasil para o filme homônimo de Carlos D iegues, constatando o esvaziamento da estrutura de sentimento em que foram criados e que ajudaram a forjar - e que continua a pairar como um fantasma sobre suas obras ${ }^{8}$.

0 modernismo nas artes brasileiras desenvolveu-se ao longo do século passado, indissociável do processo de instauração e consolidação da racionalidade capitalista moderna no Brasil - que autores como Florestan Fernandes (1976) chamariam de "revolução burguesa". As ondas modernistas desde 1922 podem ser caracterizadas contraditória esimultaneamente como românticas e modernas, passadistas e futuristas. Tomar as supostas tradições da nação e do povo brasileiro (que são "inventadas" e construídas seletivamente por autores ou movimentos específicos) como base de sustentação da modernidade foi característica dos mais diferentes movimentos estéticosa partir da Semana deArteM oderna de 1922: verde-amarelismo e Escola da Anta (1926 e 1929, aproximados na política do integralismo de Plínio Salgado), seus adversários Pau-Brasil e Antropofagia (1926 e 1928, comandados por 0 swald de Andrade), a incorporação do folclore proposta por M ário de Andrade ou por Villa-Lobos. A crítica da realidade brasileira, associada à cel ebração do caráter nacional do homem simples do 
povo, viria nos anos de 1930 e 1940, por exemplo na pintura de Portinari e nos romances regionalistas, até desaguar nas manifestações da década de 1960, herdeiras da brasilidade, agora indissociável da idéia de revolução social - fosse ela nacional e democrática ou já socialista, contando com 0 povo como agente, não mero portador de um projeto político ${ }^{9}$.

A brasilidade voluntarista consolidada nos anos de 1960 como estrutura de sentimento não pode ser dissociada do cenário internacional. Até mesmo a afirmação da nacionalidadeno período tem um componente internacional significativo. No contexto da Guerra Fria, surgiam esforços dos países "não alinhados" para organizar autonomamente o que então ficou conhecido como Terceiro M undo, para além do Primeiro M undo alinhado aos norte-americanos e do Segundo M undo, na órbita soviética. Todo o globo vivia o clima do "terceiro-mundismo", da libertação nacional diante do colonialismo e do imperialismo, da solidariedade internacional com os povos subdesenvolvidos que se libertavam em Cuba, no V ietnã, na Argélia e em outros países.

Talvez 0 adepto mais representativo desse terceiro-mundismo na cultura brasileira tenha sido Glauber Rocha, que o tornaria explícito em seu conhecido manifesto "Estética da fome", de 1965 (apud Pierre, 1996, pp. 123-131) - típico do que aqui se chama de estrutura de sentimento da brasilidade (romântico-) revolucionária. 0 documento foi influenciado pelo pensamento de Frantz Fanon, o médico negro das Antilhas que lutou na Argélia contra o colonialismo francês, autor em 1961 de 0 s condenados da terra (1979). Diz Glauber no texto, sem fazer citação explícita, mas com referência evidente a Fanon: "uma estética da violência antes de ser primitiva é revolucionária, eis aí o ponto inicial para que o colonizador compreenda a existência do colonizado: [...] foi preciso um primeiro policial morto para que o francês percebesse um argelino" (Idem, p. 129). Está também em clara afinidade com as propostas de outro ícone do terceiromundismo, o argentino que lutou em Cuba e na África, e morreu na Bolívia, Che Guevara - talvez a referência internacional mais significativa do romantismo revolucionário do período.

N esse sentido, acertadamente, D aniel Pécaut observou que se deve "evitar caricaturar o passado" - e também desmistificálo, podese acrescentar. Para Pécaut, o suposto "delírio nacional-popular" organizado em torno do Estado

$\mathrm{N}$ ão foi absolutamente apanágio de uma minoria ávida de transformar seu "saber" em "poder"; apoiava-se, como frisou M ichel D ebrun, num sentimento difundido em muitos setores sociais. 0 privilégio concedido à "libertação nacional" não ti-
9. $\mathrm{N}$ as palavras de $\mathrm{Gu}$ Ilar, referindo-se ao romance Quarup, "a realização pessoal deságua no coletivo. N ão setrata de apagar-se na massa, mas deentender que seu destino está ligado a ela" (1967, p. 256). N os termos de Glauber Rocha, em sua "estética da fome", o "miserabilismo" na literatura e nas artes em geral no Brasil até osanos de 1960 era"escrito como denúnciasocial, hoje passou a ser discutido como problemapolítico" (apud Pierre, 1996, p. 127). 
nha, então, valor algum de álibi visando a evitar a luta de classes; muito simplesmente, o Brasil vivia a hora do advento do Terceiro M undo (1990, p. 180).

O utros componentes internacionais constituintes dessa estrutura de sentimento foram as sucessivas revoluções socialistas do século XX, notadamente a soviética e depois a chinesa, a cubana e outras. Elas teriam repercussão no Brasil, especialmenteentre artistas e intelectuais, muitos do quais foram militantes de esquerda. Ademais, a estrutura de sentimento da brasilidade revolucionária não se dissociava de traços do romantismo revolucionário em escala internacional nos anos de 1960: a fusão entre vida pública e privada, a ânsia de viver o momento, a liberação sexual, a fruição da vida boêmia, o desejo de renovação, a aposta na ação em detrimento da teoria, os padrões irregulares de trabalho e a relativa pobreza de jovens artistas e intelectuais.

Portanto, não seria exagerado dizer que a experiência viva da estrutura de sentimento da brasilidade revolucionária foi uma variante nacional de um fenômeno que se espalhou mundo afora. Além das especificidades locais - no caso brasileiro, as lutas pelas reformas de base no pré-1964 e contra a ditadura após essa data - , o florescimento cultural e político na década de 1960 ligava-se a uma série de condições materiais comuns a diversas sociedades em todo o mundo: aumento quantitativo das classes médias, acesso crescente ao ensino superior, peso significativo dos jovens na composição etária da população, num cenário de crescente urbanização e consolidação de modos de vida cultural típicos das metrópoles, num tempo de recusa às guerras coloniais e imperialistas, sem contar a incapacidade do poder constituído para representar sociedades que se renovavam e avançavam também em termos tecnológicos, por exemplo com o acesso cada vez maior a um modo de vida que incorporava ao cotidiano o uso de eletrodomésticos, especialmente a televisão. Essas condições materiais por si sós não explicam as ondas de rebeldia e revolução, nem as estruturas de sentimento que as acompanharam por toda parte. M as foi em resposta às mudanças na organização social na época que se construíram certas estruturas de sentimento, como aquela da brasilidade revolucionária.

Atração e afastamento da brasilidade revolucionária

Evidentemente, nem todos os artistas e intelectuais compartilharam da estrutura de sentimento da brasilidade revolucionária nos anos de 1960. 
Para tomar um exemplo significativo, o músico da bossa nova Roberto $\mathrm{M}$ enescal conta um caso pitoresco que merece ser reproduzido:

C onfesso que nós real mente éramos alienados totais. Eu sabia o que acontecia da avenida Atlântica para o mar; passando da Barata Ribeiro já não sabia mais nada! [...] Teve um dia nessa época em que eu fui gravar no Campo de Santana [na gravadora CBS]. [...] ia gravar com a orquestra, eram uns arranjos do Luisinho Eça, equando nós chegamos no estúdio não tinha ninguém. [...] N inguém chegava, e o técnico falou: "Vamos passando a guitarra e o baixo". E passamos, gravamos a música do Tom e Aloysio de O liveira chamada "Inútil paisagem". D epois de um tempo começamos a falar: "Bom, a orquestra não vem, será quea genteerrou o dia?" [...] Aî́ deu umas 11hs da manhã e resolvemos ir embora. Pegamos o carro e saímos. Q uando fui passando ali em frente à Cinelândia, passaram uns soldados a cavalo e eu pensei: "O que está havendo, que coisa estranha...". Q uando chegamos ali perto da UNE, estava um rolo danado. Vimos que havia acontecido alguma coisa a mais. Era simplesmente o dia da revolução [1으 de abril de 1964] ea gente estava gravando "Inútil paisagem". A gente atébrincou que "I nútil paisagem" era o "melô" da revolução. M as isso é para mostrar que a alienação era total! A gente gostava era de música e pescaria, o resto a gente não sabia (2003, pp. 60-61).

0 caso ilustra como um contingente significativo de artistas estava desligado dos acontecimentos políticos. Para ficar no campo da canção popular depois de 1964, todo o pessoal da J ovem Guarda nada teve a ver com a estrutura de sentimento da brasilidade revolucionária. Vale notar que o depoimento de $M$ enescal de um lado incorpora o vocabulário de esquerda ("a alienação era total"), mas de outro refere-se ao golpe de 1964 como "revolução", expressão adotada e difundida pela direita.

Em contraste, vários bossa-novistas viriam a compartilhar de algum modo da estrutura de sentimento da brasilidade revolucionária, al guns de modo mais explícito e militante, como os pioneiros Carlos Lyra e Sérgio Ricardo, e logo em seguida N ara Leão; outros de modo mais distanciado, como Vinícius de M oraes, autor de poemas engajados no pré-1964 - publicados no Violão de rua do CPC (cf. Felix, 1962; 1963) -, bem como da letra do H ino da U NE, em 1962, com música de Carlos Lyra, eainda de 0 morro não tem vez, com Tom Jobim, em 1963, que dizia bem no espírito da época: "quando derem vez ao morro toda cidade vai cantar". Vinícius também compôs, com Edu Lobo, a canção vencedora do I Festival daTV Excelsior, em 1965. Trata-se de Arrastão, que exalta a comunidade popu- 
10.Entretanto, nesse mesmo LP, Chico Buarque gravou sua canção utópica, Rosa dos ventos, que nada tinha de resignação; ao contrário, previauma explosão revolucionária: "N uma festa amazônica/ numa explosão atlântica/ e a multidão vendo em pânico/ ea multidão vendo atônita/ ainda quetarde/ o seu despertar". lar de pescadores e seu trabalho. Também foi parceiro de Edu Lobo em canções como Zumbi, que celebra o líder negro revoltoso.

M ais tarde, Vinícius fez a maior parte da letra de Gente humilde, de Garoto, com a colaboração de Chico Buarque, que a gravou em 1970. N essa canção, fica clara a idealização dos habitantes dos arrabaldes por parte de quem os vê pela janela do trem. Versos como "tem certos dias/ em que eu penso em minha gente/ e sinto assim/ todo meu peito se apertar" são típicos da estrutura de sentimento aqui referida, que envolve a identificação dos artistas com o "homem simples" (cf. Ianni, 1968). M as essa canção em particular afasta-se do romantismo revolucionário, está muito mais para o romantismo resignado a que se referem Löwy e Sayre (1995, pp. 107-110). A resignação é evidente nos versos finais: "e aí me dá uma tristeza/ no meu peito/ feito um despeito/ de eu não ter como lutar/ e eu que não creio/ peço a D eus por minha gente/ é gente humilde/ que vontade de chorar"10.

A força da estrutura de sentimento da brasilidade revolucionária também se revela na assimilação, voluntária ou não, por seus críticos. Por exemplo, a poesia concreta dos irmãos Campos - que fazia um contraponto ao nacional-popular, valorizando a forma, e era crítica de qualquer apelo às supostas raízes autenticamente brasileiras, isto é, às origens pré-capitalistas não passou incólume ao apelo à ação política: propôs em 19610 "salto participante" em sua poesia, pelo qual se procurava afinação com os movimentos populares insurgentes, porém com uma linguagem também revolucionária (cf. H ollanda, 1981, p. 41).

O utro exemplo, agora no âmbito da canção popular: com a letra de A resposta - gravada em 1965 no LP de M arcos Valle, 0 compositor e o cantor , M arcos e Paulo Sérgio Valle deram o troco aos que os acusavam de alienados, ironizando os adeptos da canção engajada, isto é, aqueles que compartilhavam da estrutura de sentimento da brasilidade revolucionária:

Se al guém disser que teu samba não tem mais valor/ porque ele éfeito somente de paz e de amor/ não ligue não que essa gente não sabe o que diz/ não pode entender quando o samba é feliz/ o samba pode ser feito de céu e de mar/ o samba bom é aquele que o povo cantar/ de fome basta o que o povo na vidajá tem/ por que fazêlo cantar isso também?// M as é que étempo de ser diferente/ e essa gente não quer mais saber de amor/ falar de terra na areia do Arpoador/ quem pelo pobre na vida não faz nem favor/ falar de morro morando de frente pro mar/ não vai fazer ninguém melhorar. 
A letra explicita a resistência dos autores ao engajamento político, bem como critica uma elite de esquerda que fala em "povo" e "morro", quando em seu cotidiano não teria nenhuma relação com isso"11. 0 negócio dos autores era fazer um samba feliz, "feito de céu e de mar" para "o povo cantar", expressando uma vivência na Zona Sul carioca próxima daquela relatada por Roberto $M$ enescal no trecho citado anteriormente. Contudo, parece surpreendente - e atesta a força da estrutura de sentimento da brasilidade revolucionária - que pouco tempo depois, em 1968, os irmãos Valle, cujas canções já freqüentavam assiduamente as paradas de sucesso, não resistissem aos ventos daquele ano emblemático: quase todas as letras do LP Viola enluarada expressam "preocupação social", nas palavras de M arcos Valle (2004, p. 4). A canção que dá título ao LP tornou-se um clássico da canção engajada, chegando a conclamar à revolução social pela identidade entre os artistas e o povo:

A mão que toca um violão/ se for preciso faz a guerra/ mata o mundo, fere a terra/ a voz que canta uma canção/ se for preciso canta um hino - louvo a morte/ viola em noite enluarada/ no sertão é como espada/ esperança de vingança/ 0 mesmo pé que dança um samba/ se preciso vai à luta/ capoeira/ quem tem de noite a companheira/ sabe que paz é passageira/ pra defendêla se levanta e grita: eu vou/ M ão, violão, canção, espada/ e viola enluarada/ pelo campo e cidade/ porta-bandeira, capoeira/ desfilando vão cantando/ Liberdade!

Era "esperança de vingança” daqueles que sabem que "a paz é passageira" e iam desfilando e cantando em passeatas contra a ditadura, exigindo liberdade. Se preciso, o artista usaria "a mão que toca o violão" para fazer a guerra. A sonoridade da canção afasta-se da herança da bossa nova (marca dos irmãos Valle) e incorpora a tradicional viola do interior, sem contar as referências na letra ao sertão, à viola, à capoei ra e à porta-bandeira - todos símbolos das raízes da cultura popular brasileira, evocadas pelos compositores responsáveis pela canção engajada de enorme sucesso na época, como Geraldo Vandré, Theo de Barros, Edu Lobo e outros cuja origem social assemelhava-se à dos Valle. N ada mais expressivo que essa canção da estrutura de sentimento da brasilidade revolucionária. Entretanto, pouco tempo depois, acompanhando as exigências do mercado, as composições dos irmãos Valle voltariam ao seu leito habitual, muitas delas tornando-se sucessos em telenovelas da Rede Globo, fato que dá margem a uma breve observação.
11. Como a já mencionada 0 morro não tem vez etambém 0 morro, de Edu Lobo e Guarnieri, gravada por $\mathrm{N}$ ara Leão em 1964: "feio não é bonito/ o morro existe mas pede pra se acabar/.../ ama, o morro ama/ o amor aflito, 0 amor bonito que pede outra história". 
Especialmente depois de 1964, com a consolidação da indústria cultural no Brasil, surgiu um segmento de mercado ávido por produtos culturais de contestação à ditadura: livros, canções, peças de teatro, revistas, jornais, filmes etc. D e modo que a estrutura de sentimento da brasilidade revolucionária, antimercantil e questionadora da reificação, encontrava contraditoriamente grande aceitação no mercado - como atesta por exemplo o sucesso da Revista Civilização Brasi leira, publicação de esquerda em forma de livro que chegava a tirar mais de 20 mil exemplares entre 1965 e 1968. N uma escala muito mais ampla, havia o enorme sucesso de canções engajadas, por exemplo nos festivais musicais na televi são (cf. N apolitano, 2001). Eram sinais de mudanças na organização social brasileira sob a ditadura, que viriam a alterar a estrutura de sentimento constituída no pré-1964 e anunciar o seu declínio e superação, como será exposto mais adiante.

Para retomar o exemplo dos irmãos Valle, eles já diziam na canção citada de 1965 que "o samba bom éaqueleque o povo cantar". Predispunhamse assim a estar em sintonia com os sinais do mercado, sensíveis ao que 0 povo queria ouvir e cantar. 0 ra, no auge do período dos festivais tel evisivos de música popular brasileira, de 1965 a 1968, que davam índices de audiência impressionantes, o "povo" cantava as canções engajadas, que vendiam muito. D aí não ser tão surpreendente, como poderia parecer à primeira vista, que $\mathrm{M}$ arcos Valle tenha gravado o disco politicamente engajado Viola enluarada, nem que depois ele acompanhasse o que povo cantava nas telenovelas da G lobo. Seguia a direção do público (ou do mercado?), mesmo que não o fizesse de caso pensado.

Divergências e rivalidades numa estrutura de sentimento

12.0 recurso à obrade Bourdieu podeser útil, mas não é indispensável, nem necessariamente suficiente. Por exemplo, o próprio $\mathrm{W}$ illiams dá conta com muita propriedade do grupo de Bloomsbury sem usar a noção de campo (cf. Williams, 1982).
0 fato de vários artistas do período terem compartilhado da estrutura de sentimento da brasilidade revolucionária não significa que havia total identidade entre eles, que por vezes eram mesmo rivais, nem que suas obras deixassem de ser diferenciadas, ainda que de algum modo expressassem essa estrutura de sentimento no sentido de "articulação de uma resposta a mudanças determinadas na organização social" (C evasco, 2001, p. 153).

N esse aspecto, talvez valha a pena incorporar ensinamentos de Pierre Bourdieu (1996; 2001), desde que a estrutura de sentimento da brasilidade revolucionária não seja reduzida a uma espécie de doença infantil dos campos artísticos e intelectuais ainda em processo de formação ${ }^{12}$. Eles podem servir como instrumento para afinar a análise das especificidades dos 
diferentes campos artísticos, incluindo artistas que compartilham de certa estrutura de sentimento. U m exemplo: vistos hoje, fica claro pertencerem a uma mesma estrutura de sentimento filmes como 0 grande momento, dirigido por Roberto Santos em 1957, Assalto ao trem pagador, de Roberto Faria, em 1962, 0 pagador de promessas, filme de Anselmo D uarte baseado na peça homônima de $D$ ias $G$ omes, premiado em C annes em 1963, eainda outros, como A hora ea vez de Augusto M atraga, dirigido em 1965 por Roberto Santos, com base no conto de Guimarães Rosa. Todos eles valorizam a brasilidade arraigada no homem simples do povo (no campo ou habitante da periferia das grandes cidades), denunciam as desigualdades sociais, buscam desvendar "a realidade do Brasil"13, entre outras características que Ihes dá pertencimento à mesma estrutura de sentimento dos filmes do C inema N ovo, criados por cineastas tão unidos mas ao mesmo tempo tão diferentes entre si como Glauber Rocha, N elson Pereira dos Santos, Joaquim Pedro de Andrade, Cacá D iegues, Leon H irszman, Ruy Guerra, Zelito Viana, Walter Lima Jr., Gustavo D ahl, Luiz Carlos Barreto, D avid N eves, Paulo C ésar Saraceni, Eduardo Coutinho e Arnaldo Jabor. Entretanto, aqueles filmes não eram reconhecidos pelo grupo cinema-novista, que os acusava de seguir a estética holywoodiana, de ser herdeiros da Vera C ruz, de apego à narrativa clássica, enfim, de ser representantes do velho cinema que se queria combater (cf. Bernardet e Galvão, 1983, p. 156). Também os cineastas radicados em São Paulo - como João Batista deAndrade, Renato Tapajós, Francisco Ramalho, M aurice Capovilla e Luiz Sérgio Person -, embora plenamente identificados com as propostas cinema-novistas, não eram reconhecidos por eles. $\mathrm{N}$ as palavras de Renato Tapajós:

[...] embora a gente estivesse aqui em São Paulo sob o total impacto do Cinema $\mathrm{N}$ ovo - e todo mundo via o Cinema N ovo como a redenção do cinema brasileiro , na verdade São Paulo nunca esteve envolvido no Cinema N ovo, quer dizer, de pois comentava-se que o Cinema N ovo era composto por aqueles que o G lauber achava que faziam parte do Cinema $\mathrm{N}$ ovo. E como ele nunca achou que os paulistas fizessem parte do C inema N ovo, a gente corria um pouco à margem disso daí, embora fizesse todas as discussões e tentasse acompanhar todas as propostas" (entrevista ao autor, Caxambu, 21 de outubro de 1997).

As divergências não são perceptíveis só pelo recurso à noção de estrutura de sentimento, afinal ela era na essência, guardadas as distinções e peculiaridades de cada obra e autor, a mesma para todos esses cineastas. Talvez
13. N elson Pereira dos Santos afirma: “Q uanto ao conteúdo, meus filmesnão diferem muito, [...] é o reconhecimento da realidade do Bra sil" (Salem, 1987, p. 274). E ainda: "Amo 0 povo e não renuncio a essa paixão" (Idem, p. 326). Esse apego à "realidadebrasileira" ea"paixão pelo povo" foram marcantes da estrutura de sentimento da brasilidade revolucionária. 
as divergências possam ser mais bem compreendidas ao se adentrar pela lógica da constituição do campo do cinema brasileiro, no qual o grupo do Cinema $\mathrm{N}$ ovo buscava ganhar poder e prestígio, desbancando outros agrupamentos e evitando rivais.

O utro exemplo: o pessoal do Teatro O ficina teve, desde o início dos anos de 1960, uma sólida ligação com o Teatro de Arena, particularmente com Augusto Boal. Todos compartilhavam da mesma estrutura de sentimento, no caso do 0 ficina com uma influência forte também da dramaturgia e da filosofia existencialista de Sartre - que na época esteve no Brasil e, entre outras coisas, ajudou a difundir a simpatia pela revolução cubana, que incendiava o imaginário do pessoal do O ficina, como conta Renato Borghi em sua peça autobiográfica exibida em São Paulo em 2004, intitulada Borghi em revista. No livro 0 ficina: do teatro ao teato, Armando Sérgio da Silva observa que, em 1964, a encenação da peça do revolucionário russo M áximo G orki, "Pequenos burgueses, bem como o golpe de Estado no país, foram um marco decisivo na história do Teatro O ficina. A partir de então a balança que oscilava entre o existencial e o social começou a pender para esse último" (1981, p. 132). M as seria em 1967, com a encenação da peça de 0 swald de Andrade, 0 rei da vela, que 00 ficina viria a distinguirse claramente da tradição do Teatro de Arena e provocar impacto artístico e político nacionalmente no campo teatral, propondo uma "revolução ideológica eformal" queos aproximaria do nascentetropicalismo - o que remete a um último exemplo.

14. Tratei do temanum capítulo sobre Caetano Veloso (Ridenti, 2000, pp. 265-315), embora não tivesse recorrido então ao conceito de estrutura de sentimento, nem ao de campo.

15. Caetano propõe a "sensibilidadepopular", diferenciada do "populismo, substituidor da aventura estética pela adulação dos desvalidos ebarateador das linguagens" (Veloso, 1997, p. 504).
Parece que o tropicalismo musical também é constituinte - talvez o derradeiro - dessa estrutura de sentimento da brasilidade revolucionária, ao mesmo tempo que anuncia seu esgotamento e sua superação, quem sabe antevendo uma nova estrutura de sentimento ${ }^{14}$. M as ele tinha suas peculiaridades, tais como, de um lado, o acento na sintonia internacional e, de outro, a valorização e a recuperação de tradições populares do "Brasil profundo", esquecidas pela então dominante canção engajada, acusada de baratear as linguagens e de adular os desvalidos, nos termos do livro de memórias de C aetano Veloso ${ }^{15}$. Isso levaria os tropicalistas - cuja denominação fazia referência à utopia de uma civilização livre nos trópicos - a brigar em família com a brasilidade nacional-popular no campo da M PB. Essas peculiaridades e lutas de indivíduos e grupos que compartem ou não uma mesma estrutura de sentimento podem ser compreendidas lançando mão da idéia de campo para Bourdieu, como espaço de concorrência entre agentes em busca de legitimidade, prestígio e poder - ou seja, de capital social. 
O s tropicalistas baianos vinham de fora do eixo dominante culturalmente, por exemplo, nunca privaram da intimidade do círculo de expoentes da bossa nova, como Tom Jobim e V inícius de M oraes ${ }^{16}$. Sob a luz da formulação de "campo", é possível interpretar de modo inesperado um verso de M iserere nobis, parceria de Gilberto Gil e C apinam em 1968. Eles advertiam na canção que "já não somos como na chegada/ calados e magros, esperando o jantar" - como no tempo em que chegaram a São Paulo e fizeram o espetáculo engajado e de notoriedade secundária, intitulado Arena canta Bahia, sob direção de Augusto Boal, em 1965. D ois anos depois, eles já não se contentavam em ocupar posição subalterna no campo da música popular. N ão mais esperariam as sobras na porta: os tropicalistas arrombaram-na para avançar sobre o banquete na sala de jantar. M as isso vinha junto com o mesmo espírito socializante da estrutura de sentimento da brasilidade revolucionária, por exemplo, nos versos da mesma canção a evocar que "um dia seja/ para todos e sempre a mesma cerveja/ tomara que um dia de um dia não/ para todos e sempre metade do pão".

Declínio e esgotamento de uma estrutura de sentimento

Tenho usado uma interpretação de Perry Anderson (1986) sobre modernismo e modernidade para compreender o florescimento cultural e político nos anos de 1960 (cf. Ridenti, 1993; 2000). A estrutura de sentimento da brasilidade revolucionária construiu-se com base em coordenadas históricas que podem ser observadas nas sociedades que ingressam em definitivo na modernidade urbana capital ista: a "intersecção de uma ordem dominante semi-aristocrática, uma economia capitalista semi-industrializada e um movimento operário semi-insurgente". Vale dizer, historicamente, 0 modernismo caracteriza-se: 1) pela resistência ao academicismo nas artes, intimamenteligado a aspectos pré-capitalistas na cultura ena política, nas quais as classes aristocráticas e latifundiárias dariam o tom; 2) pelas invenções industriais de impacto na vida cotidiana, geradoras de esperanças libertárias no avanço tecnológico; e3) pela "proximidade imaginativa da revolução social", fosse ela mais "genuína e radicalmente capitalista" ou socialista (Anderson, 1986, pp. 18-19). Essas coordenadas teriam desaparecido na Europa depois da Segunda Guerra M undial, segundo o autor, mas ainda estariam presentes no Terceiro $M$ undo, que entretanto também tenderia a superá-las.

Parece que as coordenadas históricas do modernismo propostas por Anderson estavam presentes na sociedade brasileira do final dos anos de
16. Tom Jobim eViníciusdeM oraeseram íntimose parceiros do jovem Chico Buarque, atacado pelostropicalistas a ponto de responder com 0 artigo " $\mathrm{N}$ em toda loucura é genial, nem toda lucidez é ve Iha' (Buarque, 1968). 
1950 até 1968: era significativa a luta contra o poder remanescente das oligarquias rurais e suas manifestações políticas e culturais, havia um otimismo modernizador com o salto na industrialização a partir do governo Kubitschek, sem contar o imaginário da revolução brasileira - fosse ela democrático-burguesa (de libertação nacional) ou socialista -, impulsionado pelos movimentos sociais de então.

0 quadro mudaria após o fechamento político com a promulgação do Ato Institucional no 5 (AI-5), de 13 de dezembro de 1968, seguido da derrota das esquerdas brasileiras, esmagadas pela ditadura - que, paralelamente à repressão, realizava o "milagre econômico" que consolidaria a modernização conservadora -, sem contar os rumos pouco favoráveis para os revolucionários dos eventos políticos internacionais na dédada de 1970, especialmente em sua segunda metade. Com isso, desapareciam na sociedade brasileira as coordenadas históricas apontadas por Anderson: afastava-se a proximidade imaginativa da revolução, enquanto a sociedade se modernizava e urbanizava, permitindo constatar que a industrialização e as novas tecnologias não levaram à libertação mas, ao contrário, conviviam bem com uma ditadura. Assim, dissolviam-se as bases históricas que de ram vida ao florescimento cultural e político animado pela estrutura de sentimento da brasilidade revolucionária.

A ditadura, entretanto, tinha ambigüidades: com a mão direita punia duramente os opositores que julgava mais ameaçadores - até mesmo artistas e intelectuais -, e com a outra atribuía um lugar dentro da ordem não só aos que docilmente se dispunham a colaborar, mas também a intelectuais e artistas de oposição. Concomitante à censura e à repressão política, ficaria evidentena década de 1970 a existência de um projeto modernizador em comunicação e cultura, atuando diretamente por meio do Estado ou incentivando o desenvolvimento capitalista privado. A partir do governo G eisel (1975-1979), com a abertura política, especialmente por intermé dio do M inistério da Educação e Cultura, que tinha à frente N ey Braga, 0 regime buscaria incorporar à ordem artistas de oposição.

$N$ esse período, instituições governamentais de incentivo à cultura ganharam vulto, caso da Embrafilme, do Serviço N acional de Teatro, da Funarte, do Instituto $\mathrm{N}$ acional do Livro e do Conselho Federal de Cultura. A criação do M inistério das Comunicações, da Embratel e outros investimentos governamentais em telecomunicações buscavam a integração e segurança do território brasileiro, estimulando a criação de grandes redes de televisão nacionais, em especial a Globo, que nasceu, floresceu e se 
tornou uma potência na área à sombra da ditadura, que ajudava a legitimar em sua programação, especialmente nos telejornais. A G lobo empregava também artistas que compartilhavam da estrutura de sentimento da brasilidade revolucionária, como Vianinha e Dias $\mathrm{G}_{\text {omes }}{ }^{17}$.

Intelectuais como Sérgio Paulo Rouanet e Renato O rtiz já salientaram que indústria cultural brasileira dos anos de 1980, a Rede G lobo à frente, seria uma herança caricatural mas reveladora das propostas nacionais e populares da década de 1960. Rouanet admite que o "nacional-popular do passado era crítico e mobilizador, o da indústria cultural é conformista e apolítico", mas seria um "espelho deformante" daquele, do qual tirou

[...] a idéia de autenticidade que a mídia interpreta como defesa do mercado brasileiro contra os enlatados americanos e a preocupação com a identidade cultural, que a televisão procura resgatar, reservando um espaço para programações regionais, intercaladas entre programas de âmbito nacional. É dele, enfim, que vem seu traço mais típico, o antielitismo, concebido como repúdio à cultura "erudita" [...] (Rouanet, 1988, p. D.3)

Assim, haveria "afinidades estruturais importantes entre a autolegitimação nacionalista e populista da indústria cultural brasileira [atual] e as antigas bandeiras nacionalistas e populares" (I dem, p. D.3).

Já Renato O rtiz, em A moderna tradição brasileira (1988), ressalta a reabsorção despolitizante pelos meios de comunicação de massa de uma cultura nacional e popular que se pretendia revolucionária em sua origem. Se gundo ele - lançando mão da distinção entre ideologia e utopia nos termos de Karl M annheim (1950) -, a utopia nacional-popular das décadas de 1940, 1950 e 1960 transformou-sena ideologia da indústria cultural brasileira dos anos de 1970 e 1980, isto é, uma visão de mundo crítica foi transformada numa justificativa da ordem. Para usar um vocabulário inspirado em Raymond W illiams, pode-se falar no declínio da estrutura de sentimento da brasilidade revolucionária, que deixa de ser revolucionária, mas conserva aspectos de defesa da brasilidade que marcarão a indústria cultural brasileira.

Sergio M iceli (1994) chegou a levantar a hipótese de que o sucesso de bens culturais brasileiros em âmbito nacional etambém no mercado interna cional - como no caso das telenovelas da Rede G lobo - seria indissociável do
17. Até o final da vida, apesar de ter-se tornado um ícone da ideologia nacional-popular de mercado da Globo com suas telenovelas, $D$ iasGomesidentificava-se com a brasilidade revolucionária, tanto que deu a suas memórias o título Apenas um subversivo (1998).

[...] recrutamento de toda uma geração de técnicos, escritores e artistas comprometidos com a ética e a estética de esquerda e, por essa razão, habilitados artesanal 
e ideologicamente à fabricação de bens culturais condizentes com as expectativas axiológicas e com os padrões estéticos de gosto dos públicos consumidores nos países metropolitanos (M iceli, 1994, p. 60).

Com apoio estatal, durante a ditadura, foi criada uma indústria cultural merecedora desse nome, não apenas televisiva, mas também editorial que publicava livros e especialmente jornais, revistas, fascículos e outros produtos -, fonográfica, de agências de publicidade e assim por diante. Freqüentemente, empregavam-se artistas e intelectuais nas agências de publicidade, cujo crescimento vertiginoso acompanhou a modernização conservadora promovida pelo Estado, que se tornou ainda um anunciante fundamental para os meios de comunicação de massa (cf. Arruda, 1985).

Os herdeiros do Cinema Novo constituem exemplo significativo do rearranjo pragmático dos artistas de esquerda com a ordem estabelecida na década de 1970. Como bem aponta José M ário O rtiz Ramos, referindo-se ao início do Cinema N ovo, "o conceito de alienação se entrecruzava com 0 nacionalismo, costurando o tecido que sustentava, e de al guma forma unificava, a diversidade da produção cultural da época" (1983, p. 75). 0 Cinema N ovo em seus primórdios buscava um "enigmático homem brasileiro", em sua "ânsia de apreender a realidade brasileira" (Idem, p. 13). Pode-se dizer que essas palavras de Ramos expressam bem a estrutura de sentimento da brasilidade (romântico-) revolucionária, que dava resposta a certas transformações na organização social até 1964. M as essa organização mudaria muito sob a ditadura, especialmente depois de 1968, e portanto a estrutura de sentimento correspondentenão poderia passar incólume. N esse sentido, Ramos observa com perspicácia a permanência para os herdeiros do Cinema N ovo - e, pode-se acrescentar, para os herdeiros em geral da estrutura de sentimento da brasilidade revolucionária - da questão nacional, da identidade do cinema, da cultura e do homem brasileiro, mas mostra como essa questão vai ganhando novos contornos ao longo do tempo: "A preocupação com o 'homem brasileiro' é uma constante no Cinema N ovo, mas o importante é acompanhar as transformações que sofre conforme as injunções políticas" (Idem, p. 78).

Essas injunções políticas tendiam a afastar a proximidade imaginativa da revolução social. A pós as derrotas de 1964 e de 1968, a busca romântica da identidade nacional do homem brasileiro permaneceria, porém mudavam as características desse romantismo, que foi deixando de ser revolucionário para encontrar um lugar na nova ordem. N os primeiros anos da ditadura, os 
herdeiros do Cinema N ovo posicionaram-se claramente na oposição, mas isso em parte mudou com a abertura política do presidente $G$ eisel ea reorganização da Embrafilme, com a qual vários cineastas passaram a colaborar, especialmente na gestão do cineasta Roberto Farias, entre 1974 e 1979 (cf. Soler Jorge, 2002; Ramos, 1983). A posição do governo continuava ambígua: filmes financiados pela Embrafilme por vezes eram censurados, diferentes órgãos do Estado incentivavam e puniam uma dada produção.

Essa ambigüidade - em parte responsável pela longevidade da ditadura marcaria todas as efferas artísticas e também intelectuais, como a própria universidade: o governo reprimia professores e estudantes considerados subversivos, mas o projeto de desenvolvimento exigia investimentos significativos em ciência e tecnologia, portanto, também na universidade. O ra, os debates e a crítica próprios da atividade acadêmica acabaram por gerar questionamentos crescentes à ditadura, que não deixava de oferecer uma alternativa de acomodação institucional a setores acadêmicos de oposição, como a criação de um sólido sistema nacional de pós-graduação e de apoio à pesquisa que perdura atéhoje. A atuação educacional do regimeimplicou também a massificação do ensino público de primeiro e segundo graus, ainda que qualitativamente degradados, o incentivo ao ensino médio e superior privado e assim por diante. Buscava atender à sua maneira, dentro da nova ordem, às reivindicações de modernização que haviam levado os estudantes às ruas na década de 1960.

A sociedade brasileira foi ganhando nova feição, artistas e intelectuais que compartilharam da estrutura de sentimento da brasilidade revolucionária aos poucos iam-se adaptando à ordem sob a ditadura. Chegaram a constituir um segmento de produção e consumo de mercadorias culturais consideradas críticas ao regime, que censurava seletivamente al guns desses produtos. 0 mercado oferecia ótimas oportunidades a profissionais qualificados - até mesmo aos artistas de esquerda, representantes da cultura viva do período anterior, que se esgotara em 1968. Eles não tinham muita dificuldade para encontrar bons empregos em redes de rádio e televisão, produtoras de teatro e cinema, empresas de jornalismo, agências de publicidade, universidades, fossem órgãos públicos ou privados - ainda que houvesse "listas negras" elaboradas pelo Serviço N acional de Informações.

Herança de uma estrutura de sentimento

A partir de 1985, a redemocratização da sociedade brasileira levaria uma parcela significativa de artistas e intelectuais de oposição a comprometer-se 
18. Não obstante, como no caso dePedrosa, o impacto daestruturade sentimento da brasilidade revolucionária no contexto da ditadura éperceptível em seu pensamento no período. Vejase, por exemplo, o elogio do crítico - adepto daarteabstrata eimpulsionador do concretismo nas artes plásticas brasileiras - ao engaja mento da exposição 0 pinião 65, inspirada no show 0 pinião, um "teatro popular tão próximo, por sua própria natureza, ao clima social, à atmosfera política da época". Para ele, a canção Carcará, de Jã̃o do Vale, seria um "verdadeiro hino da revolução camponesa nordestina [...] como a Caramagnolefoi da plebe urbana e dos sans-culottes na $R e$ volução Francesa, durante o Terror". Carcará e o filme D euseo diabo na terra do sol, de Glauber Rocha, teriam dado "para o Brasil o signo de uma espéciede criatividade coletiva" (apud Arantes, 1995, pp. 204-205).

19. A Brasiliense também editou na época a coleção 0 nacional e o popular na cultura brasileira, planejada por com a N ova República. Eram as "aves de arribação", a deixar a esfera de uma oposição mais consistente à ordem estabel ecida, nos termos de um artigo da época deFrancisco deO liveira (1985). Já restava pouco da velha estrutura de sentimento da brasilidade revolucionária, que entretanto - adaptada à nova organização social a que procurava responder - encontraria uma sobrevida em al guns setores, como os que viriam a constituir o Partido dosTrabalhadores (PT ), que desdeo início contou com a simpatia de vários artistas eintelectuais. Tanto que M ário Pedrosa, Antonio C andido e Lélia Abramo encabeçam as assinaturas do $M$ anifesto de Lançamento do PT, em 10 de fevereiro de 1980, em ato público realizado no Colégio Sion, em São Paulo. C ontudo, sintomaticamente, esses três sempre tiveram uma convivência problemática e contraditória com a estrutura de sentimento da brasilidade revolucionária, a que entretanto não eram alheios. Politicamente, $M$ ário e Lélia tinham formação trotskista e C andido integrava o Partido Socialista, todos adversários do trabalhismo, bem como do nacionalismo dos comunistas ${ }^{18}$.

Em 1980, as condições eram outras: a sociedade havia se modernizado e urbanizado, o nacionalismo terceiro-mundista era coisa do passado, o culto ao povo cedia lugar no imaginário do PT à constituição da classe trabalhadora, assim como se esgotava a noção de partido de vanguarda informada pelo marxismo-leninismo. $\mathrm{N}$ ão havia como a estrutura de sentimento da brasilidade revolucionária expressa nas obras artísticas dos anos de 1960 permanecer. Contudo, os movimentos sociais insurgentes, o novo sindicalismo, as Comunidades Eclesiais de Base da I greja informadas pela Teologia da Libertação, a luta contra a ditadura nos seus estertores, o surto da imprensa alternativa, o fim do Al-5 e da censura, a Anistia, a vitória da revolução na N icarágua em 1979 e outros fatores criavam em setores artísticos e intelectuais - identificados ou não com os primórdios do PT - a sensação de continuidade em relação à antiga estrutura de sentimento. Tanto que, por exemplo, no final da década de 1970, a editora Civilização Brasileira tentou reeditar o sucesso da Revista Civilização Brasileira ao lançar Encontros com a Civilização Brasile ra (que chegou a ter mais números que a antiga, mas seu impacto não foi nem sombra do da outra), a também tradicional editora Brasiliense viveria tempos de glória após o sucesso da Coleção Primeiros Passos, que atualizava a proposta de livros paradidáticos de bolso dos Cadernos do povo brasileiro, editados no início dos anos de 1960 pela C ivilização Brasileira ${ }^{19}$, e até a pequena editora Kairós, dirigida por trotskistas, lançou a prestigiosa Arte em Revista, que republicou parte significativa dos debates político-estéticos da década de 1960. 
No decorrer dos anos de 1980, as lutas sindicais no Brasil, a campanha pelas diretas-já, o fim da ditadura no início de 1985, a convocação da Assembléia N acional Constituinte, a legalização dos partidos comunistas, 0 crescimento do PT e outros fatores ainda mobilizaram certo imaginário da revolta e da revolução, mesmo que já distinto daquele dos anos de 1960: destacavam-se correntes de esquerda que buscavam contato com a realidade imediata das vidas cotidianas e com as lutas dos movimentos sociais por direitos de cidadania, contra a visão doutrinária fechada de certas vertentes do marxismo ${ }^{20}$. Por outro lado, o cenário internacional desfavorável, com o avanço do neoliberalismo, o domínio conservador simbolizado na dupla Reagan-T hatcher e no pontificado de João Paulo II, a crise da revolução nicaragüense, a glasnost e a Perestroika na União Soviética, que culminariam com o fim do socialismo no Leste Europeu, e internamente a derrota dos candidatos de esquerda Brizola e Lula, nas eleições de 1989, parecem ter selado a sorte da velha estrutura de sentimento.

De sapos revolucionários a príncipes pós-modernos

Esse processo evidentemente é longo e intrincado, não seria possível dar conta dele satisfatoriamente em poucas linhas. Por isso, aqui se propõe apenas um comentário sobre um filme recente que não foi propriamente um sucesso de público nem de crítica, mas que expressa bem o deslocamento e o estranhamento em nossos dias do artista/intelectual formado na estrutura de sentimento da brasilidade revolucionária - e assim serve de pretexto para tratar do envelhecimento dessa estrutura. Trata-se de 0 príncipe, lançado em 2002, escrito e dirigido por U go G iorgetti - um cineasta nascido em 1942, diretor-roteirista de cinema publicitário desde 1966, também documentarista, que só se destacaria nos longas a partir de meados dos anos de 1980. 0 personagem central de 0 príncipeé Gustavo, um intelectual que deixou São Paulo no início dos anos de 1980 e só volta ao Brasil vinte anos depois, quando reencontra os amigos e a cidade muito modificados, sentindo-se absolutamente deslocado.

Aqui é preciso dar um desconto à verossimilhança, afinal, em primeiro lugar, o homem que retorna não havia vivido em outro planeta, mas em Paris, ainda que trabal hando sem regularidade e recorrendo constantemente à ajuda da seguridade social, pelo seu ideal de estar à margem do sistema. Em segundo lugar, o personagem central seria mais plausível se pertencesse à geração do diretor, universitária nos anos de 1960, plenamente identifi-
Adauto N ovaes (1983), que não deixava de ser um balanço crítico da estrutura de sentimento da brasilidade revolucionária.

20. Trato de aspectos desse problema em Ridenti (1998), sobre o impacto no Brasil do livro deM arshall Berman (1986). 
21. É significativaalonga fala, quase um monólogo, desse personagem cínico e arrivista, numa cena de cerca de cinco minutos que se passanuma academiade ginástica da moda, em que se recorre a outros símbolos dos novos-ricos, como telefone celular, terno e carro importado. Eisalgunstrechos: "finalmente, cultura e erudição estão dando dinheiro. A modernidade inclui a cultura e os culturati. A modernidadenecessita de charme. E quem é que pode fornecer essa matéria-prima tão rara? $\mathrm{N}$ ós! Finalmente nós estamosnamoda. Háfenômenosacontecendo, mega-livrarias sendo inauguradas, feiras de livros, o diabo. N ão sei seal guém lê, mas compram, e isso éo que interessa para nós. [...] O s intelectuaiscansaram de ser pobres. Eles acabaram aprendendo com os publicitários que ideiazinhas valem dinheiro. E, apesar de tudo, há muito dinheiro circulando por aí. Todososnossosamigos estão colocados. [...] etodosestão nas colunas sociais. A gente acaba fazendo parte da grande fraternidade ar- cada com a estrutura de sentimento da brasilidade revolucionária - mas G ustavo é mais jovem, formado na década de 1970, deveria estar mais afinado com os ecos dos novos movimentos sociais que surgiram na época em São Paulo (cf. Sader, 1988). H á uma breve menção a eles, durante uma fala que remete ao tempo da "Vila Euclides" - estádio de futebol onde se realizavam manifestações dos metalúrgicos do ABC do fim dos anos de 1970 ao início dos de 1980 - , ao passo que abundam as referências à década de 1960, por exemplo uma tomada na rua M aria Antônia, passando em frente à antiga Faculdade de Filosofia.

Após vinte anos de exílio voluntário, ao retornar de táxi do aeroporto à casa materna na V ila $\mathrm{M}$ adal ena - que na sua juventude era um bai rro pacato e simples, onde viviam jovens estudantes eintelectuais, muitos dos quais freqüentavam o campus vizinho da U niversidade de São Paulo - , G ustavo mal reconhece o bairro, agitado, cheio de bares, movimento de pessoas e automóveis, sujeito à criminalidade eà banalidade da violência cotidiana da metrópole. O s antigos amigos de esquerda em geral estão bem situados dentro da ordem, com a qual convivem com graus variados de (des)conforto. U m deles tornou-sejornal ista de prestígio - o "velho" do jornal queteria um profissional para agradar a cada segmento do mercado. Ele, paraplégico em razão de um acidente, vive bêbado e a tudo ironiza. N uma cena marcante, recita versos da $D$ ivina comédia no célebre trecho em que o poeta está às portas do inferno. A cena tem lugar de madrugada, em meio a uma infinidade de mendigos nas proximidades da outrora fulgurante Galeria M etrópole, atrás da decadente Biblioteca M unicipal, diante da estátua de $D$ ante na praça D om José G aspar, onde ficava o Paribar, também evocado explicitamente numa tomada (detal he: todas essas referências remetem à São Paulo florescente dos anos de 1950/1960, tempo da juventude do autor do filme, e não do personagem da Vila M adalena na década de 1970).

O utro amigo prosperou com marketing gerencial e cultural; sabendo do bom domínio de Gustavo da obra de M aquiavel, propõe ao velho companheiro empresariar seu futuro sucesso: pal estras e um livro adaptando a obra 0 prínci pe para auto-ajuda de interessados em triunfar rapidamente nosnegócios ${ }^{21}$. D aí o título do filme, que se refere também à autodesignação de Gustavo como "o príncipe da N áusea”, em referência ao romance de Sartre - que, de novo o deslocamento temporal, empolgou muito mais a geração do diretor do filme que a de seu personagem. A bela ex-namorada tornou-se executiva bem-sucedida de uma grande empresa que investe em eventos artísticos e culturais, mas se confessa infeliz. O utros personagens 
aparecem brevemente, como a moça que fotografa mortos na violência da madrugada, um psicanalista da moda que será homenageado no desfile de uma escola de samba e um maestro que vira pop star (papel de Júlio M edaglia, que ironicamente interpreta um maestro engolfado no sistema).

Só dois personagens parecem manter a dignidade. 0 primeiro é um amigo de Gustavo que ajuda os pobres, trabal hando de graça no al bergue do Bom Retiro; leva uma vida modesta e recebe G ustavo para conversar numa pequena fábrica abandonada que herdou do pai. Esse personagem mais que o niilista G ustavo - éo que melhor encarna o que restou da brasilidade revolucionária. Elediz, numa cena: "existeum Brasil secreto, subterrâneo, escuro, enorme, é difícil chegar perto. E ao mesmo tempo ele está praticamentepor toda parte". 0 segundo éo sobrinho do protagonista, um professor de História que está em tratamento mental numa clínica após surtos sucessivos que não poupavam sequer suas aulas no colégio particular em que lecionava. Constatando a falta de expressão da $\mathrm{H}$ istória do Brasil, eleensinava aos al unos uma $\mathrm{H}$ istória grandiosa queinventava, por exemplo atribuindo aos militares brasileiros a libertação de Berlim no fim da Segunda Guerra M undial. Ao final do filme, o professor não suportou a doença que chamara de "desabamento central da alma", constatou que "a luz desta cidade está se apagando" e jogou-se do alto do viaduto sobre a avenida Sumaré, enquanto o protagonista sai para o exterior, fugindo novamente (das ruínas) de São Paulo e do Brasil.

0 filme permite um paralelo com o livro de Jacoby (1990) sobre 0 declínio do intelectual atuante na vida pública da sociedade norte-americana ainda nos anos de 1950. Jacoby aponta o desaparecimento do espaço urbano barato e agradável que podia nutrir uma intelligentsia boêmia e modelar uma geração de intelectuais, com a eliminação das moradias, restaurantes, cafés elivrarias modestos, somada à comercial ização acelerada da cultura eà restrição da vida intelectual aos limites dos campi universitários, situados nos subúrbios. N esse ambiente, "a literatura e a crítica se tornam carreiras, não vocações", com autores independentes dando lugar à profissionalização da vida cultural. A institucionalização de intelectuais e artistas neutralizaria a liberdade de que em teoria dispõem, de modo que um eventual sonho com a revolução conviveria com o investimento na profissão, no qual prevaleceria a realidade cotidiana da burocratização e do emprego.

Como expressa bem a traj etória dos personagens do filme de Giorgetti, há tempos entrou em declínio o padrão de intelectual ou artista de esquerda dos anos de 1960, engajado, em busca da ligação com o "povo" - hoje tístico-empresarial - eganha dinhero, porra!". 
22. Ao tratar do conceito dehegemonia, basea do em Gramsci, Raymond Williams observa que ele envolve "um conjunto de práticas e expectativas, sobrea total idade da vida: nossos sentidos e distribuição deenergia, nossa percepção de nós mesmos e nosso mundo. É um sistema vivido de significados e valores - constitutivo econstituidor que, ao serem experimentados como práticas, parecem confirmarse reciprocamente. Constitui assim um senso da realidade para a maioria das pessoas na sociedade, um senso de realidade absoluta, porque experimentada, e além da qual é muito difícil paraamaioriados membros da sociedade movimentar-se, namaioria dasáreas desua vida" (W illiams, 1979, p. 113). considerado talvez como epifenômeno do "populismo", manipulador dos anseios populares, expressão de uma minoria em busca de transformar seu saber em poder, ou, na melhor das hipóteses, como protótipo do intelectual quixotesco. Aos poucos, foi-se estabelecendo o modelo do artista e do scholar contemporâneos, profissionais amadurecidos, desvinculados de compromissos ideológicos e sociais, livres das utopias voluntaristas dos anos de 1960, que só teriam sido revolucionárias na aparência. O u de artistas e intelectuai s que mantêm uma fachada de engajamento e ligação com o passado para legitimar sua acomodação com a ordem no presente.

$\mathrm{N}$ ão seria o caso de aprofundar aqui a análise do filme, que interessa por ilustrar o estranhamento de alguém formado na estrutura de sentimento da brasilidade revolucionária em relação à realidade de hoje, em que a hegemonia burguesa é tão difusa e consolidada que se torna difícil pensar numa alternativa a ela. $\mathrm{N}$ ão há dúvida de que hoje predomina 0 "senso de realidade experimentada"22 que supõe a reprodução eterna da sociabilidade capitalista.

A antiga estrutura de sentimento da brasilidade revolucionária por certo tem herdeiros, mas há muito deixou de ser predominante, em vários casos transformou-se numa ideologia legitimadora da indústria cultural brasileira. Pode-se arriscar a hipótese - seria melhor dizer intuição, pois ela é difícil de comprovar, uma vez que ainda não há o devido distanciamento no tempo - de que o lugar principal é agora ocupado pela estrutura de sentimento da individualidade pós-moderna, esboçada naqueles mesmos anos de 1960, caracterizada pela val orização exacerbada do "eu", pela crença no fim das visões de mundo totalizantes, dado o caráter completamente fragmentado e ilógico da realidade, pela sobreposição eclética de estilos e referências artísticas e culturais de todos os tempos, pela valorização dos meios de comunicação de massa e do mercado, pela inviabilidade de qualquer utopia.

0 profissional competente e competitivo no mercado, concentrado na carreira e no próprio bem-estar, veio substituir o antigo modelo de artista/ intelectual indignado, dilacerado pelas contradições da sociedade capitalista periférica e subdesenvolvida, que compartilhava da estrutura de sentimento da brasilidade revolucionária. C ontudo, a utopia revolucionária não desaparece nem mesmo na produção cultural reificada da sociedade de nossos dias (cf. Jameson, 1994). M as isso já seria tema para outro artigo. 
Referências Bibliográficas

Anderson, Perry. (1986), "M odernidade e revolução". N ovos Estudos Cebrap, São Paulo, 14: 2-15.

Arantes, O tília (org.). (1995), Política das artes - M ário Pedrosa. Textos escolhidos. São Paulo, Edusp.

Arruda, M aria Arminda N ascimento. (1985), A embalagem do sistema: a publicidade no capitalismo brasileiro. São Paulo, D uas Cidades.

Berm An, M arshall. (1986), Tudo que é sólido desmancha no ar. São Paulo, Cia. das Letras.

Bern ARdet, Jean-Claude \& Galvão, M aria Rita. (1983), 0 nacional e o popular na cultura brasileira - cinema. São Paulo, Brasiliense.

Bourdieu, Pierre. (1996), As regras da arte. São Paulo, Cia. das Letras. . (2001), "C ampo de poder, campo intelectual e'habitus' de classe". In:

A economia das trocas simbólicas. São Paulo, Perspectiva.

Buarque, Chico. (1968), "N em toda loucura é genial, nem toda lucidez é velha". Ú Itima H ora, São Paulo, 9 dez.

(1999), Entrevista a M arcos Augusto G onçalves e Fernando de Barros e Silva. Folha de São Paulo, Caderno 4, 18 mar., p. 8.

Callado, Antonio. (1967), Quarup. Rio de Janeiro, Civilização Brasileira.

Cevasco, M aria Elisa. (2001), Para ler Raymond Williams. São Paulo, Paz eTerra.

FAN O N, Frantz. (1979), O s condenados da terra. Rio de Janeiro, Civilização Brasileira. Favaretto, Celso. (1996), Tropicália alegoria alegria. São Paulo, Ateliê Editorial.

Felıx, M oacyr (org.). (1962), Violão de rua: poemas para a liberdade. Rio de Janeiro, Civilização Brasileira, vols. I, II.

(org.). (1963), Violão de rua: poemas para a liberdade. Rio de Janeiro, Civilização Brasileira, vol. III.

Fern And Es, Florestan. (1976), A revolução burguesa no Brasil. Rio de Janeiro, Zahar. Gom Es, Dias. (1998), A penas um subversivo: autobiografia. Rio de Janeiro, Bertrand Brasil.

GulLAR, Ferreira. (1967), "Q uarup ou ensaio de deseducação para brasileiro virar gente". Revista Civilização Brasileira, Rio de Janeiro, 15: 251-258, set.

H olLAN DA, H eloísa Buarque de. (1981), Impressões de viagem: CPC, vanguarda e desbunde: 1960/70. São Paulo, Brasiliense.

I anNI, O ctavio. (1968), "A mentalidade do 'homem simples' ". Revista Civilização Brasileira, Rio de Janeiro, ano III, 18: 113-117, mar./abr.

JACoBy, Russell. (1990), O súltimos intelectuais. São Paulo, Edusp/Trajetória Cultural. Jam Eson, F. (1994), "Reificação e utopia na cultura de massa”. Crítica M arxista, São Paulo, 1 (1): 1-25. 
KUSHNIR, Beatriz (org.). (2002), Perfis cruzados: trajetórias e militância política no Brasil. Rio de Janeiro, Imago.

LöWy, M ichael \& SAYRe, Robert. (1995), Revolta e melancolia: o romantismo na contramão da modernidade. Petrópolis, Vozes.

M ann heim, Karl. (1950), I deologia e utopia. Porto Alegre, Globo.

M en escal, Roberto. (2003), "A renovação estética da Bossa N ova”. In: D uarte, Paulo Sérgio \& N Aves, Santuza C ambraia (orgs.). D o samba-canção à tropicália. Rio de Janeiro, Relume Dumará.

M ICELI, Sergio. (1994), "O papel político dos meios de comunicação de massa”. In: Sosn owskı, Saul \& Schwarz, Jorge (orgs.). Brasil: o trânsito da memória. São Paulo, Edusp.

N Apo LitAn O, M arcos. (2001), Seguindo a canção: engajamento político e indústria cultural na M PB (1959-1969). São Paulo, Annablume/Fapesp.

N ovaes, Adauto. (1983), Prefácios aos volumes da coleção 0 nacional e o popular na cultura brasileira. São Paulo, Brasiliense.

O liveira, Francisco de. (1972), "Economia brasileira: crítica à razão dualista". Estudos Cebrap, São Paulo, 2. . (1985), "Aves de arribação: a migração dos intelectuais". Lua N ova, São Paulo, 2 (3): 20-6, out./dez.

O RTIZ, Renato. (1988), A moderna tradição brasileira: cultura brasileira e indústria cultural. São Paulo, Brasiliense.

Pécaut, D aniel. (1990), O s intelectuais e a política no Brasil. São Paulo, Ática.

Pierre, Sylvie. (1996), Glauber Rocha. Campinas, Papirus.

Prado J R., Caio. (1966), A revolução brasileira. São Paulo, Brasiliense.

Ram os, José M ário O rtiz. (1983), Cinema, Estado e lutas culturais (anos 50/60/70). Rio de Janeiro, Paz e Terra.

RidentI, M arcelo. (1993), 0 fantasma da revolução brasileira. São Paulo, Editora daU nesp. . (1998), "O sucesso no Brasil da leitura do M anifesto Comunista feita por

M arshall Berman". In: Reıs Filho, Daniel Aarão (org.). 0 M anifesto Comunista 150 anos depois. Rio de Janeiro/São Paulo, Contraponto/Fundação Perseu Abramo. . (2000), Em busca do povo brasilei ro: artistas da revolução, do CPC à era da TV. Rio de Janeiro, Record.

Rom An 0, Roberto. (1981), Conservadorismo romântico: origem do totalitarismo. São Paulo, Brasiliense.

Rouanet, Sérgio Paulo. (1988), "Nacionalismo, populismo e historismo". Folha de São Paulo, Caderno D , 12 mar., p. 3.

SADER, Eder. (1988), Q uando novos personagens entram em cena. Rio de Janeiro, Paz e Terra. 
Salem, H elena. (1987), N elson Pereira dos Santos: o sonho possível do cinema brasileiro. Rio de Janeiro, N ova Fronteira.

Saliba, Elias Thomé. (1991), As utopias românticas. São Paulo, Brasiliense.

Schwarz, Roberto. (1978), "Cultura e política, 1964-1969". In: O pai de família e outros estudos. Rio de Janeiro, Paz e Terra.

Sılva, Armando Sérgio da. (1981), O ficina: do teatro ao teato. São Paulo, Perspectiva. So ler J ORge, M arina. (2002), Cinema N ovo eEmbrafilme: cineastas eE stado pela consolidação da indústria cinematográfica brasileir ra. D issertação de M estrado, Campinas, IFCH , U nicamp.

V ALle, M arcos. (2004), D epoimento para o encarte do CD Antologia, compilado por Charles Gavin.

Veloso, Caetano. (1997), Verdade tropical. São Paulo, Cia. das Letras. W ILliam S, Raymond. (1979), M arxismo e literatura. Rio de Janeiro, Zahar. . (1982), "T he Bloomsbury fraction". In: . Problemsin materialism and culture. Londres, Verso. . (1987), D rama from Ibsen to Brecht. Londres, The Hogarth Press.

\section{Resumo}

Artistas e intelectuais no Brasil pós-1960

0 artigo trata da trajetória de intelectuais brasileiros considerados de esquerda, especial mente os artistas, a partir dos anos de 1960. D esenvolve-se a hipótese da existência de uma "estrutura de sentimento" da brasilidade revolucionária, forte até 1968, em resposta a mudanças na organização social, e de como ela tendeu a desestruturar-se quando a sociedade seguiu em outra direção. As obras dos artistas que compartilhavam dessa estrutura de sentimento eram diferenciadas e não havia total identidade entre eles, às vezes rivais entre si. 0 processo de modernização conservadora da socie dade viria a institucionalizar profissional mente o meio artístico e intelectual, afastando-o do compromisso com as causas críticas da ordem. Esgotaram-se as coordenadas históricas em que frutificou certa estrutura de sentimento que, não raro, converteu-se em ideologia legitimadora da indústria cultural brasileira.

Palavras-chave: Cultura e política; Intelectualidade brasileira; Rebeldia e revolução; Estrutura de sentimento; Romantismo revolucionário.

\section{Abstract}

Artists and intellectuals in post-1960 Brazil

This article is about the progress of Brazilian left wing intellectuals, especially the artists, after the 1960's. In it, we devel op the hypothesis of the existence of a structure of feelings of revolutionary Brazilianism, strong until 1968, as an answer to changes in 
social organization, and how it tended to become destructured when the whole of society went in another direction. The works by the artists who shared this structure of feelings shared something familiar but there was no total identity among them; at times, they were rivals. The process of conservative modernization of society would professionally institutionalize the artistic and intellectual milieu, keeping it apart from the commitment with critical causes of order. The historical constraints in which certain structures of feelings bore fruit dried up, and, many times, those feelings were transformed into an ideology that legitimized the Brazilian cultural industry. Keywords: C ultureand politics; Brazilian intellectuals; Rebellion and revolution; Structure of feelings; Revolutionary romanticism.

Texto recebido em 29/ 9/2004 e aprovado em $16 / 11 / 2004$.

M arcelo Ridenti é professor do D epartamento deSociologia do Instituto deFilosofiaeCiências H umanas da Universidade Estadual de Campinas (Unicamp) e pesquisador do CN Pq. E-mail: mridenti@ unicamp.br 